\title{
REDUCING REGIONAL INCOME DIFFERENTIALS WITH CAPITAL TRANSFERS IN THE \\ SELF-MANAGEMENT ECONOMY: YUGOSLAVIA, $1947-1965: \quad$ COMMENT
}

Uwe Jan Woltemade

Ohio Wesleyan University

While the authors have given us an informative account of some of the aspects of regional development in Yugoslavia, they basically have approached the subject-mannerwith too narrow an economic perspective. They neglected to discuss sufficiently the supportive measures referred to and, more important, did not take cognizance of the larger politicoeconomic policyframework within the "regional experiment" was undertaken.

Mazek and Hocevar, while stressing that investment flow to the Yugoslav South was heavy, admit that per capita investment the re was below the Yugoslav average. This, in the light of low education/skill levels and insufficient social overhead capital, is a very significant matter, much more so than seems to come out in the paper. Kiril Miljovski appropriately wrote: "To aim at achieving faster sustained development of the underdeveloped areas and to invest per capita continually less than average in these areas is to expect the impossible". 1 Still, considerable industry grew up in the South, offering welcome employment opportunities.

As mentioned, this discussant appreciates the remarks regarding supportive policies but finds them too brief.

The authors maintain that "undue duplication of facilities in the South" resulted and describe critics of the "experiment" as stating that it reduced national growth. One must ask: What were the regional development options? Earlier decentralization and reliance on the market presumably. This might have avoided "duplication" and given rise to a higher Yugoslav growth rate but very likely at the expense of sharper have/have-not contrasts which, in that country, would have been considerably more dangerous than in good many other lands. Moreover, the decentralization experience of the last few years shows (and mentioned by Mazek and Hocevar) that interregional investment flows have been meager and that republic implosion is far from over. Just recently an article in the New York Times Magazine told us that "Serbian authorities floated a popular bond is sue last year to help finance construction of a railway line from Belgrade to the Montenegrin seacoast at Bar - an old Serb nationalist dream because such a railway avoids Croat territory. The Croat leaders promptly followed suit by floating 'their' loan for 'their' highway from Zagreb to the Croatian port of Split. "2

The development of "backward" areas and closing of income gap must be seen in the policy light of the day. Jack Fisher commented: "Economic criteria have been less of a rationale for investments than the constitutional provisions which suggests that equity must be shown to each of the six republics." And, "the path the Yugoslavs chose proved to be an institutional compromise between these two compelling forces: a high rate of development and policies aimed at easing inter-group conflict. 13 The authors of the paper and all of us must analyze the investment programs in questions as part of the larger socialistic fabric andoverall planning. The idea that diminution of regional differences in standards of living and opportunities was essential for the attainment of a promising and exciting socialism constituted a key ing redient of the "experiment." This matter must receive careful attention. 


\section{FOOTNOTES}

l Kiril Miljovski, 'Nedovoljno Razvijena Produčja i Sedmogodišnji Plan," Ekonomist, 3-4 (1963), p. 671, quoted in F. E. Ian Hamilton. Yugoslavia: Patterns of Economic Activity (New York: Praeger, 1968), p. 141.

${ }^{2}$ Anatole Shub, "After Tito - Who CanKeep Together The Serbs, Croats, Slovenes, Macedonians, Bosnian Moslems, Albanians, Hungarians and Montenegrins?", The New York Times Magazine (January 16, 1972), p. 44.

${ }^{3}$ Jack C. Fisher, Yugoslavia - A Multinational State (San Francisco; Chandler, 1966), pp. 9, 13. 